\title{
Quality and vitamin A status assessment of different commercial edible oil
}

\author{
S. A. Lisa*, S. Khan, M. A. Kabir, F. Islam, S. Mohajan and K. Chowdhury \\ Institute of Food Science and Technology, Bangladesh Council of Scientific and Industrial Research, Dhanmondi, Dhaka-1205, \\ Bangladesh
}

Received: 15 February 2018

Revised: 13 March 2018

Accepted: 23 May 2018

DOI: https://doi.org/10.3329/bjsir.v54i1.40726

\begin{abstract}
The present study was done to evaluate the quality and the vitamin A fortification status of 5 types of commercial edible oils sold in Dhaka city markets. The percentages of free fatty acid (FFA), peroxide value (POV), iodine value (IV) and fatty acid composition were estimated to evaluate the quality and vitamin A content were determined to evaluate the vitamin A fortification status of 25 commercial edible oils- soybean oil, sunflower oil, rice bran oil, mustard oil and palm olein ( 5 brands of each). The results revealed that FFA, POV and IV of the commercial oils analyzed were within the BSTI standard limits. The highest saturated fatty acids (SFA) values ranging from $39.85 \pm 0.005$ to $46.97 \pm 0.002 \%$ was found in palm olein samples and the lowest SFA values ranging from 4.56 \pm 0.031 to $6.97 \pm 0.096 \%$ was found in mustard oils. On the other hand, mustard oils contained highest monounsaturated fatty acids (MUFA) ranging from $69.30 \pm 0.189$ to $75.87 \pm 0.069 \%$ compared to other oils analyzed. Highest polyunsaturated fatty acids (PUFA) were recorded in sunflower oils $64.78 \pm 0.035 \%$ followed by soybean oils $63.25 \pm 0.245 \%$. In addition, except sunflower and mustard oils, vitamin A was found in all the soybean and rice bran oils analyzed. On the contrary, vitamin A was found only in $60 \%$ of the palm olein samples analyzed and the content was much lower than the standard value (15-30 ppm).
\end{abstract}

Keywords: Vegetable oils; Vitamin A; Fatty acid composition; Peroxide value; Free fatty acid; Iodine value

\section{Introduction}

Fats/oils are an essential part of balanced diet which comprises almost $25 \%$ of total caloric intake (Zambiazi et al., 2007). People consume fats and oils for three purposes: as energy source, as a structural component and to make powerful biological regulators (Llorent-Martinez et al., 2011). Nowadays oils from plant source have gained immense popularity than animal fat due to its special feature of unsaturation.

The major quality attributes of edible oils can be evaluated by determining the free fatty acid (FFA), peroxide value and iodine value, which indicate the extent of hydrolytic and oxidative rancidity of the oil and degree of unsaturated fatty acids, respectively (Chowdhury et al., 2014). Fats/oils are mainly composed of three types of fatty acids-saturated (SFA), monounsaturated (MUFA) and polyunsaturated
(PUFA) fatty acids that are usually consumed by the people. Thus, fatty acid profiling of oil is very important for human diet.

Although high levels of PUFAs are more susceptible to oxidation resulting quality deterioration and development of undesirable odour, but they play an important role in maintaining the ratio of LDL to HDL cholesterol in blood. On the other hand, high level of PUFAs is responsible in forming trans fatty acids during heating that may lead to risk of cardiovascular disease (Beardsell et al., 2002). Saturated fatty acids (SFAs) increase oil stability, but they are responsible for increasing LDL concentration in blood, and high LDL level resulted in blood clotting and vascular smooth muscle proliferation (Zambiazi et al., 2007). Nevertheless, 
essential fatty acids (EFAs) including linolenic acid (an omega-3 fatty acid) and linoleic acid (an omega-6 fatty acid) cannot be synthesized in the body, thus should be supplemented through edible oil because these EFAs are important for maintaining good health and normal development (Simopoulos, 2002).

In developing countries, vitamin A deficiency is a serious health problem and it was estimated that 250000 to 500000 vitamin A-deficient children become blind every year, half of them dying within 12 months of losing their sight (WHO, 2018). Thus vitamin A fortification of edible oil could be an effective and sustainable strategy to combat vitamin A deficiency in a country. As vitamin A is a fat soluble vitamin and oil is an ideal matrix for vitamin A fortification thus, Bangladesh government enacted 'National Edible Oil Fortification Law, 2013' in November, 2013 (UNICEF Factsheet, 2014). Bangladesh Standards and Testing Institute (BSTI) set standards for 4 types of fortified oils except mustard oil and controls quality of the edible oil market. Therefore, it is very important to know the status of vitamin A fortification in the commercial etible oil samples as they aimed to reduce vitamin A deficiency mainly among women and children. Thus, this study was designed to evaluate the existing commercial oil quality and also to assess the current vitamin A fortification status of commercial oils available in the Dhaka city markets.

\section{Materials and methods}

\section{Vegetable oils}

Total 25 edible oil samples of five types (soybean oil, sunflower oil, rice bran oil, mustard oil and palm olein, each from 5 different brands) were collected from local market of Dhaka city, Bangladesh during the month of February, 2015. The samples were coded as SB1, SB2, SB3, SB4 and SB5 for soybean oil; SF1, SF2, SF3, SF4 and SF5 for sunflower oil; RB1, RB2, RB3, RB4 and RB5 for rice bran oil; MT1, MT2, MT3, MT4 and MT5 for mustard oil, and PO1, PO2, PO3, PO4 and PO5 for palm olein oil, respectively.

\section{Standard and chemicals}

Fatty Acid Methyl Ester (FAME) and vitamin A (Retinyl Palmitate) standards were collected from Sigma-Aldrich, St. Louis, Missouri, USA. All the chemicals used in this study were of analytical grade, Merck, Germany. HPLC grade Methanol and Dichloromethane were used for HPLC analysis and GC grade petroleum ether (b.p. $40-60^{\circ} \mathrm{C}$ ) was used for GC analysis.

\section{Chemical analysis}

Free fatty acid, peroxide value and iodine value of the samples were done following AOAC method 940.28, AOAC 965.33 and AOAC 920.158 respectively (AOAC, 2005).

\section{Analysis of fatty acid composition}

\section{Preparation of fatty acid methyl ester (FAME)}

Relative concentration of fatty acid (FA) from oil samples were measured as their corresponding methyl esters. 5-7 drops of oil was taken in $15 \mathrm{ml}$ test tube and $3 \mathrm{ml}$ of $0.5 \mathrm{M}$ sodium methoxide (prepared by mixing metallic sodium in methanol) was added and digested by stirring in a boiling water bath for about 15 minutes. It was allowed to cool to room temperature and $1 \mathrm{ml}$ of petroleum ether (b.p $40-60^{\circ} \mathrm{C}$ ) was added followed by $10 \mathrm{ml}$ deionized water, mixed gently and allowed to settle for 5-6 minutes. The distinct upper layer of methyl ester in petroleum ether was separated carefully in a capped vial and used for analysis. $200 \mathrm{mg}$ of different fatty acid standard in their respective methyl ester form were dissolved separately in $10 \mathrm{ml}$ petroleum ether (b.p $40-60^{\circ} \mathrm{C}$ ) in a series of screw-capped test tubes. Aliquots of $1 \mu \mathrm{l}$ fatty acid methyl ester (FAME) were injected and the peaks of fatty acids were recorded for their respective retention time and areas by the data processor unit of GC.

\section{Gas chromatography}

Fatty acid composition was analyzed using gas chromatograph (Shimadzu GC-14B, Japan) equipped with flame ionization detector and fused silica capillary column (FAMEWAX, Crossbond ${ }^{\circledR}$ polyethylene glycol, $15 \mathrm{~m} \times 0.25 \mathrm{~mm} \times 0.25 \mu \mathrm{m}$ film thickness, Restek; Pennsylvania, USA). Splitless injection technique with nitrogen as carrier gas at a constant flow rate of $20 \mathrm{ml} / \mathrm{min}$ was used. Injector temperature was $250^{\circ} \mathrm{C}$, initial oven temperature was $150^{\circ} \mathrm{C}$ and held for 5 minutes. Temperature was increased at a rate of $8^{\circ} \mathrm{C} / \mathrm{min}$ to $190^{\circ} \mathrm{C}$ and then increased to $200^{\circ} \mathrm{C}$ at a rate of $2^{\circ} \mathrm{C} / \mathrm{min}$ and held for 10 minutes. The fatty acids were identified by using respective fatty acid methyl ester standards (FAME mix) and presented as relative percentage done by the automated GC software (Class GC-10,version-2.00).

\section{Vitamin A estimation}

Vitamin A was determined using High Performance Liquid Chromatograph (Shimadzu Corporation, Japan) equipped with a main controlling unit (SCL-10AVP), two high 
pressure pumps (LC-10ATVP), a degasser (DGU-14A), a column oven (CTO-10ASVP) with $20 \mu \mathrm{L}$ injector loop and a UV detector (SPD-10AVP) controlled by a single Class VP software along with a Luna C18 column $(250 \mathrm{~mm}$ X $4.6 \mathrm{~mm}$ I.D., $5 \mu \mathrm{m}$ particle size).

\section{Extraction of vitamin $A$}

Samples were prepared by dissolving $10 \mathrm{~g}$ of each oil samples with dichloromethane and methanol in $50 \mathrm{ml}$ amber color volumetric flask. The standard stock solution was prepared by dissolving $0.005 \mathrm{~g}$ of retinyl palmitate in $50 \mathrm{ml}$ dichloromethane and methanol to get a final concentration of $100 \mathrm{mg} / \mathrm{ml}$. Both sample and standard were sonicated in ultrasonic bath for 5 minutes and then filtered with $0.45 \mu \mathrm{m}$ syringe filter in a $1.5 \mathrm{ml}$ glass vial and an aliquot of the overlay was injected into the HPLC column. All of the standards and samples were run in triplicate.

\section{HPLC condition}

Detection was performed at $325 \mathrm{~nm}$ using UV-VIS Detector for vitamin A as Retinyl Palmitate. Absolute methanol was used as the elution solvent. The analytical column was kept at $30^{\circ} \mathrm{C}$. The separation was done using isocratic mode. Flow rate was $1 \mathrm{ml} / \mathrm{min}$ and run time for each standard and sample was 60 minutes. The sample injection volume was $20 \mu \mathrm{L}$. Vitamin A (as retinyl palmitate) concentration was determined with external standards. Data was collected and processed by Class-VP Automated Software (Shimadzu Corporation).

\section{Statistical analyses}

Data analysis was performed using Statistical Package for the Social Sciences (SPSS version 15.0 SPSS Inc. Chicago, Illinois, U.S.A). Data were expressed as mean \pm SEM (standard error of the mean) and means were separated using t-test. One-way ANOVA was used for determining the significance/non-significance of results.

\section{Results and discussion}

\section{Free fatty acid (FFA)}

FFA value, which is an indicator of degree of hydrolytic rancidity, of the five commercial vegetable oils were shown in Table I, irrespective of types of commercial oils. FFA values of all the oil samples were found to be $<0.30 \%$, which is the maximum permissible limit set by Codex standard (CODEX-STAN 210 - 1999) and BSTI standard (BDS 1769: 2014, BDS 1773: 2016, BDS 1886: 2014, BDS 1770: 2014 and BDS 25: 2014) for edible oils. In Soybean oils, maximum
FFA value was recorded as $0.12 \%$ in SB3 sample and the minimum was recorded as $0.03 \%$ in $\mathrm{SB} 2$ sample. On the other hand, FFA values were recorded as $0.06 \%, 4.5 \%$ and $5.35 \%$ respectively, in SB1, SB4 and SB5 samples that are significantly different from each other. In sunflower oils, highest FFA value was found in SF5 (0.21\%) and lowest in SF1 and SF4 (0.04\%). FFA value of SF2 (0.12\%) and SF3 $(0.14 \%)$ were found not significantly different. In case of Rice bran oil, the RB3 sample showed highest FFA value $(0.21 \%)$ and the lowest values was found as $0.07 \%$ in RB2 and RB4 samples. FFA value of RB1 (0.13\%) and RB5 $(0.11 \%)$ were not significantly different. In palm olein samples, the lowest value $(0.02 \%)$ was found in PO4 sample while highest in PO2 $(0.22 \%)$. FFA values of PO1, PO3 and PO5 were recorded as $0.04 \%, 0.14 \%$ and $0.20 \%$ respectively. In case of mustard oil, non-significant differences in FFA value were observed among the sample tested, $0.15 \%, 0.19 \%$, $0.22 \%, 0.20 \%$ and $0.19 \%$ correspondingly. FFA value of any vegetable oil depends on the refining process of that oil (Egbuna, 2015). Therefore, the variation of FFA in all samples except mustard oil was due to variation of refining process.

\section{Peroxide value (POV)}

Peroxide value (POV) is considered as oxidation indicator that is limited to early stage of rancidity (Chowdhury et al., 2014). In this study, peroxide value of five commercial oils were analyzed and presented in Table I. The results showed that POV of soybean oils- SB1, SB2, SB3, SB4 and SB5 were $2.23,4.53,2.41,4.53$ and $5.35 \mathrm{meq} \mathrm{O}_{2} / \mathrm{kg}$, respectively. The highest POV $\left(5.35 \mathrm{meq} \mathrm{O}_{2} / \mathrm{kg}\right)$ was observed in SB5 compared to other oil samples, where SB2 \& SB4 samples, and SB1 \& SB3 samples were not significantly different (Table I). Among the sunflower oils analyzed, SF1 had the lowest POV (4.35 meq $\mathrm{O}_{2} / \mathrm{kg}$ ) and SF2 had the highest POV ( $7.30 \mathrm{meq} \mathrm{O}_{2} / \mathrm{kg}$ ). On the other hand, the POV of SF3, SF4 and SF5 samples were 6.16, 5.52 and $6.34 \mathrm{meq} \mathrm{O}_{2} / \mathrm{kg}$, respectively. All the samples were varied significantly from each other except SF3 and SF5. The POV of rice bran oil were found $1.54,4.34,3.39,5.52$ and $2.41 \mathrm{meq} \mathrm{O}_{2} / \mathrm{kg}$ in $\mathrm{RB} 1$, $\mathrm{RB} 2, \mathrm{RB} 3, \mathrm{RB} 4$ and RB5 that varied significantly from each other. In case of palm olein, POV was also varied significantly among each other where PO5 sample showed minimum POV (1.32 meq $\left.\mathrm{O}_{2} / \mathrm{kg}\right)$ and PO1 showed the maximum POV (5.60 meq $\mathrm{O}_{2} / \mathrm{kg}$ ), while other samples, $\mathrm{PO} 2$, PO3 and PO4 showed POV value of 4.58, 2.20 and 3.57 respectively (Table I). The POV value of mustard oil varied significantly except for MT1 and MT3 samples, whereas MT4 sample showed the lowest POV (1.72 meq $\left.\mathrm{O}_{2} / \mathrm{kg}\right)$ and MT5 showed the highest POV (6.66 meq $\left.\mathrm{O}_{2} / \mathrm{kg}\right)$ value. The POV of MT1, MT2 and MT3 was recorded as 2.35, 3.45 and 
Table I. FFA, POV and IV (Mean \pm SEM) of the vegetable oils

\begin{tabular}{|c|c|c|c|c|}
\hline Sample Name & Sample Code & FFA \% & $\begin{array}{c}\mathrm{POV} \\
\left(\text { meq O}_{2} / \mathrm{kg}\right)\end{array}$ & IV \\
\hline \multirow[t]{5}{*}{ Soybean Oil } & SB1 & $0.06 \pm 0.003^{b}$ & $2.23 \pm 0.155^{\mathrm{c}}$ & $128 \pm 2.03^{\mathrm{a}}$ \\
\hline & SB2 & $0.03 \pm 0.009^{c}$ & $4.53 \pm 0.151^{b}$ & $125 \pm 1.16^{\mathrm{ab}}$ \\
\hline & SB3 & $0.12 \pm 0.014^{\mathrm{a}}$ & $2.41 \pm 0.134^{\mathrm{c}}$ & $121 \pm 1.20^{\mathrm{b}}$ \\
\hline & SB4 & $0.07 \pm 0.003^{b}$ & $4.53 \pm 0.179^{b}$ & $121 \pm 1.45^{b}$ \\
\hline & SB5 & $0.08 \pm 0.007^{b}$ & $5.35 \pm 0.089^{\mathrm{a}}$ & $125 \pm 1.20^{\mathrm{ab}}$ \\
\hline \multirow[t]{5}{*}{ Sunflower Oil } & SF1 & $0.04 \pm 0.006^{\mathrm{r}}$ & $4.35 \pm 0.149^{\mathrm{s}}$ & $132 \pm 0.88^{p}$ \\
\hline & SF2 & $0.12 \pm 0.015^{\mathrm{q}}$ & $7.30 \pm 0.081^{\mathrm{p}}$ & $128 \pm 1.53^{\mathrm{pq}}$ \\
\hline & SF3 & $0.14 \pm 0.018^{q}$ & $6.16 \pm 0.067^{q}$ & $128 \pm 2.03^{\mathrm{pq}}$ \\
\hline & SF4 & $0.04 \pm 0.009^{\mathrm{r}}$ & $5.52 \pm 0.135^{\mathrm{r}}$ & $125 \pm 1.86^{\mathrm{q}}$ \\
\hline & SF5 & $0.21 \pm 0.015^{\mathrm{p}}$ & $6.34 \pm 0.091^{\mathrm{q}}$ & $125 \pm 0.58^{\mathrm{q}}$ \\
\hline \multirow[t]{5}{*}{ Rice Bran Oil } & RB1 & $0.13 \pm 0.012^{y}$ & $1.54 \pm 0.101^{\mathrm{z}}$ & $95 \pm 0.33^{y}$ \\
\hline & $\mathrm{RB} 2$ & $0.08 \pm 0.007^{\mathrm{z}}$ & $4.37 \pm 0.149^{\mathrm{w}}$ & $98 \pm 1.20^{y}$ \\
\hline & RB3 & $0.21 \pm 0.009^{\mathrm{x}}$ & $3.39 \pm 0.094^{\mathrm{x}}$ & $96 \pm 1.20^{\mathrm{y}}$ \\
\hline & RB4 & $0.07 \pm 0.003^{z}$ & $5.52 \pm 0.170^{\mathrm{v}}$ & $102 \pm 0.88^{x}$ \\
\hline & RB5 & $0.11 \pm 0.012^{\mathrm{y}}$ & $2.41 \pm 0.137^{\mathrm{y}}$ & $97 \pm 1.20^{\mathrm{y}}$ \\
\hline \multirow[t]{5}{*}{ Mustard oil } & MT1 & $0.15 \pm 0.05^{1}$ & $2.35 \pm 0.141^{\mathrm{n}}$ & $101 \pm 0.67^{1}$ \\
\hline & MT2 & $0.19 \pm 0.012^{1}$ & $3.45 \pm 0.055^{\mathrm{m}}$ & $96 \pm 1.20^{1}$ \\
\hline & MT3 & $0.22 \pm 0.009^{1}$ & $2.38 \pm 0.142^{\mathrm{n}}$ & $101 \pm 2.08^{1}$ \\
\hline & MT4 & $0.20 \pm 0.009^{1}$ & $1.72 \pm 0.113^{\circ}$ & $98 \pm 1.86^{1}$ \\
\hline & MT5 & $0.19 \pm 0.008^{1}$ & $6.66 \pm 0.075^{1}$ & $97 \pm 1.53^{1}$ \\
\hline \multirow[t]{5}{*}{ Palm Olein } & PO1 & $0.04 \pm 0.003^{f}$ & $5.60 \pm 0.07^{\mathrm{d}}$ & $55 \pm 1.53^{\mathrm{e}}$ \\
\hline & $\mathrm{PO} 2$ & $0.22 \pm 0.007^{\mathrm{d}}$ & $4.58 \pm 0.119^{\mathrm{e}}$ & $61 \pm 0.882^{\mathrm{d}}$ \\
\hline & $\mathrm{PO} 3$ & $0.14 \pm 0.015^{\mathrm{e}}$ & $2.20 \pm 0.126^{\mathrm{g}}$ & $54 \pm 0.882^{\mathrm{e}}$ \\
\hline & $\mathrm{PO} 4$ & $0.02 \pm 0.003^{\mathrm{f}}$ & $3.57 \pm 0.187^{\mathrm{f}}$ & $60 \pm 0.882^{\mathrm{d}}$ \\
\hline & PO5 & $0.20 \pm 0.009^{\mathrm{d}}$ & $1.32 \pm 0.160^{\mathrm{h}}$ & $54 \pm 1.53^{\mathrm{e}}$ \\
\hline
\end{tabular}

Values with the same superscript in the column are not significantly different $(\mathrm{p}>0.05)$.

2.38 meq $\mathrm{O}_{2} / \mathrm{kg}$, respectively. Irrespective of types of oils, the average POV of the sunflower oils (SF2) was found highest (5.93 meq $\mathrm{O}_{2} / \mathrm{kg}$ ) this higher peroxide value might be due to auto-oxidation of unsaturated fatty acids because sunflower oil is the richest sources of polyunsaturated fatty acids (Khan et al., 2015). In addition, the variation of peroxide value may also depends on the initial composition, concentration of minor compounds with antioxidants properties, pro-oxidant characteristics, degree of processing, and storage conditions, which might causes different oxidative stability and deterioration of oils (Crapiste et al., 1999). Nonetheless, peroxide values of all samples were within the acceptable limit (maximum 10.0 meq $\mathrm{O}_{2} / \mathrm{kg}$ ) of edible oil according to the Codex (CODEX-STAN 210 - 1999) standard. 


\section{Iodine value (IV)}

Iodine value indicates the relative amount of unsaturated fatty acid contents in the lipids (Fursule et al., 2006). As shown in Table I, iodine values of soybean oils, sunflower oils, rice bran oils, mustard oils and palm oleins differed from 121 to 128, 125 to 132,95 to 102,96 to 101 and 54 to 55 respectively which are substantial in respect to BSTI Standard value (BDS 1769: 2014, BDS 1773: 2016, BDS 1770: 2014, BDS 1886: 2014 and BDS 25: 2014). Among the soybean oils, iodine values of SB1, SB2, SB3, SB4 and SB5 were found 128, 125, 121, 121 and 125 respectively. Iodine values of SB2, SB3, SB4 and SB5 were not significantly differing from each other. In case of SB1, SB2 and SB5, iodine values also followed same pattern. Similarly, the iodine value of sunflower oils, SF1, SF2 and SF3 were almost similar and SF2, SF3, SF4 SF5 followed the same pattern. Iodine values of SF1, SF2, SF3, SF4 and SF5 were found $132,128,128,125$ and 125 respectively. In rice bran oils, RB1, RB2, RB3, RB4 and RB5 had the iodine value- 95, 98, 96, 102 and 97. The iodine value of RB4 was significantly higher than others (RB1, RB2, RB3 and RB5) but in case of RB1, RB2, RB3, RB5, the difference was not significant. In case of mustard oils, the difference among all the samples was not significant where iodine value of MT1, MT2, MT3, MT4 and MT5 were 101, 96, 101, 98 and 97 respectively. The iodine values of palm oleins were 55, 61, 54, 60 and 54 respectively. PO1, PO3 and PO5 were not varied significantly from each other but varied significantly from PO2 and PO4 which have almost similar iodine values. In the study, similarities in iodine values were higher than $\mathrm{FFA} \%$ and PV among the same type of samples. If oils can be shielded from air and light with special precautions, the iodine value may usually be kept unchanged for an indefinite period when quite pure (Chowdhury et al., 2014).

\section{Fatty acid composition}

\section{Saturated fatty acids}

Saturated fatty acids (SFA) are fatty acids without double bonds (Schwingshackl and Hoffmann, 2012). Distribution of saturated fatty acids of different oils was illustrated in Table II.

In the present study, lauric acid (C12:0) and myristic acid (C14:0) was not detected in most oils except palm oleins. In palm oleins, lauric acid (C12:0) ranged from 0.235 to $2.56 \%$. The myristic acid (C14:0) ranged from 0.818 to $1.87 \%$. Highest content of both lauric acid (C12:0) and myristic acid (C14:0) was found in PO4 while least in PO3. Similarly, behenic acid (C22:0) was only found in soybean oil (ranged from 0.217 to $0.284 \%$ ) and sunflower oil (ranged from 0.514 to $0.105 \%$ ). In soybean oil, highest content of Behenic was found in SB5 sample. On the other hand, in case of sunflower oil it was highest in SF4. Palmitic acid (C16:0), one of the most frequent saturated fatty acids available in oils and fats (Ratledge, 2004) have been found in highest amount in palm oleins ranging from 36.49 to $41.09 \%$ compared to other oil brands. The least palmitic acid was found in the mustard oil samples ranging from 2.02 to $3.74 \%$ only. In case of soybean oil it ranged from 10.78 to $11.87 \%$ but not significantly varied among the samples. In case of sunflower oil, it ranged from 6.29 to $7.46 \%$. In rice bran oils, it ranged from 19.51 to $22.83 \%$. Another common saturated fatty acid is stearic acid (C18:0) which was present in all samples.In soybean oil, sunflower oil, rice bran oil, mustard oil and palm olein, it ranged from 3.73 to $4.81 \%, 0.79$ to $3.29 \%, 1.38$ to $2.09 \%, 1.18$ to $3.20 \%$ and 2.04 to $4.67 \%$ respectively. Lauric acid (C12:0), myristic acid (C14:0) and palmitic acid (C16:0) are considered to enhance cholesterol levels, whereas stearic acid (C18:0) has little or no effect (Miller et al., 2000). Arachidic acid (C20:0) was found in all types of oils, however, in case of soybean oil, Arachidic acid only detected in sample SB5 (0.285\%). In sunflower oil, the value of Arachidic acid ranged from 0.169 to 0.418 . Highest amount was found in SF4 which was significantly higher than all other samples. Other samples of sunflower oil did not vary significantly. In rice bran oil, it ranged from 0.556 to $1.66 \%$ and highest amount was found in sample RB5 while least in RB1. In Mustard oil, it ranged from 0.667 to $1.24 \%$. Highest amount was found in MT3 while least in MT1.All the samples varied significantly except MT1 and MT4. In case of palm olein, arachidic acid levels did not vary significantly with each other.

Total saturated fatty acid level was found maximum in palm oleins (39.85 to $46.97 \%$ ) and minimum in mustard oils (4.56 to 6.97) where the individual values were significantly different. In case of soybean, sunflower and rice bran oils, the value of total saturated acid ranged from 14.76 to $16.25 \%$, 8.38to $10.44 \%$ and 23.14 to $24.77 \%$ respectively. The results are in agreement with some previous studies where total saturated fatty acids of soybean oil, sunflower oil, rice bran oil, mustard oil and palm oleins were almost 13.5 to $18 \%, 8$ to $12 \%, 18$ to $25 \%, 13$ to $17 \%$ and 46 to $50 \%$ respectively (Chowdhury et al., 2007; Kostik et al., 2013; Zambiazi et al., 2007). Although intake of saturated fatty acids like palmitic, 
lauric and myristic acid may be harmful to health as they raise both total cholesterol and LDL cholesterol in the bloodstream (Beardsell et al., 2002), saturated fatty acids have an influence on less peroxides and trans fat formation. acids (MUFA) and polyunsaturated fatty acids (PUFA) of different oil have been shown in Table III. Palmitoleic acid (C16:1) were not detected in soybean oil, rice bran oil and mustard oil whereas detected in sunflower oil and palm Olein. However, in sunflower oil, it was not detected in sample SF1. In sunflower oil, the level of palmitoleic acid was ranged

Table II. Saturated fatty acids (SFA)* (Mean \pm SEM) in the vegetable oils

\begin{tabular}{|c|c|c|c|c|c|c|c|c|}
\hline $\begin{array}{l}\text { Sample } \\
\text { Name }\end{array}$ & $\begin{array}{c}\text { Sample } \\
\text { Code }\end{array}$ & $\begin{array}{c}\text { Lauric } \\
(\%)\end{array}$ & $\begin{array}{c}\text { Myristic } \\
(\%)\end{array}$ & $\begin{array}{c}\text { Palmitic } \\
(\%)\end{array}$ & $\begin{array}{c}\text { Stearic } \\
(\%)\end{array}$ & $\begin{array}{c}\text { Arachidic } \\
(\%)\end{array}$ & $\begin{array}{c}\text { Behenic } \\
(\%)\end{array}$ & $\begin{array}{c}\text { Total SFA } \\
(\%)\end{array}$ \\
\hline Soybean & SB1 & ND & ND & $10.96 \pm 0.334^{\mathrm{a}}$ & $4.23 \pm 0.147^{b}$ & $\mathrm{ND}^{\mathrm{b}}$ & $0.247 \pm 0.040^{\mathrm{a}}$ & $15.44 \pm 0.189^{\mathrm{ab}}$ \\
\hline \multirow[t]{4}{*}{ Oil } & SB2 & ND & ND & $10.78 \pm 0.309^{\mathrm{a}}$ & $3.74 \pm 0.062^{\mathrm{c}}$ & $\mathrm{ND}^{\mathrm{b}}$ & $0.243 \pm 0.060^{\mathrm{a}}$ & $14.76 \pm 0.314^{b}$ \\
\hline & SB3 & ND & ND & $11.05 \pm 0.150^{\mathrm{a}}$ & $3.73 \pm 0.102^{\mathrm{c}}$ & $\mathrm{ND}^{\mathrm{b}}$ & $\mathrm{ND}^{\mathrm{b}}$ & $14.78 \pm 0.249^{b}$ \\
\hline & SB4 & ND & ND & $11.37 \pm 0.240^{\mathrm{a}}$ & $4.18 \pm 0.114^{b}$ & $\mathrm{ND}^{\mathrm{b}}$ & $0.217 \pm 0.062^{\mathrm{a}}$ & $15.77 \pm 0.257^{\mathrm{a}}$ \\
\hline & SB5 & ND & ND & $10.87 \pm 0.133^{\mathrm{a}}$ & $4.81 \pm 0.131^{\mathrm{a}}$ & $0.285 \pm 0.021$ & $0.284 \pm 0.014^{\mathrm{a}}$ & $16.25 \pm 0.260^{\mathrm{a}}$ \\
\hline Sunflower & SF1 & ND & ND & $6.45 \pm 0.070^{g}$ & $3.29 \pm 0.025^{\mathrm{e}}$ & $0.192 \pm 0.012^{f}$ & $0.514 \pm 0.011^{\mathrm{h}}$ & $10.44 \pm 0.079^{\mathrm{d}}$ \\
\hline \multirow[t]{4}{*}{ Oil } & SF2 & ND & ND & $6.53 \pm 0.015^{\mathrm{fg}}$ & $2.97 \pm 0.022^{\mathrm{f}}$ & $0.174 \pm 0.013^{\mathrm{f}}$ & $0.688 \pm 0.024^{\mathrm{f}}$ & $10.35 \pm 0.052^{\mathrm{d}}$ \\
\hline & SF3 & ND & ND & $6.29 \pm 0.023^{\mathrm{h}}$ & $1.23 \pm 0.022^{\mathrm{h}}$ & $0.193 \pm 0.001^{\mathrm{f}}$ & $0.669 \pm 0.015^{\mathrm{fg}}$ & $8.38 \pm 0.014^{\mathrm{g}}$ \\
\hline & SF4 & ND & ND & $7.46 \pm 0.026^{\mathrm{e}}$ & $0.79 \pm 0.008^{\mathrm{i}}$ & $0.418 \pm 0.001^{\mathrm{e}}$ & $1.05 \pm 0.021^{\mathrm{e}}$ & $9.72 \pm 0.009^{\mathrm{f}}$ \\
\hline & SF5 & ND & ND & $6.57 \pm 0.022^{\mathrm{f}}$ & $2.55 \pm 0.008^{\mathrm{g}}$ & $0.169 \pm 0.0003^{\mathrm{f}}$ & $0.627 \pm 0.001^{\mathrm{g}}$ & $9.92 \pm 0.028^{\mathrm{e}}$ \\
\hline Rice Bran & RB1 & ND & ND & $22.83 \pm 0.176^{\mathrm{p}}$ & $1.38 \pm 0.086^{\mathrm{r}}$ & $0.556 \pm 0.014^{\mathrm{s}}$ & ND & $24.77 \pm 0.223^{\mathrm{p}}$ \\
\hline \multirow[t]{4}{*}{ Oil } & $\mathrm{RB} 2$ & ND & ND & $21.81 \pm 0.128^{q}$ & $1.75 \pm 0.058^{\mathrm{q}}$ & $0.579 \pm 0.0006^{\mathrm{rs}}$ & ND & $24.15 \pm 0.094^{\mathrm{q}}$ \\
\hline & RB3 & ND & ND & $20.88 \pm 0.088^{\mathrm{r}}$ & $1.60 \pm 0.032^{\mathrm{qr}}$ & $0.656 \pm 0.016^{\mathrm{r}}$ & ND & $23.14 \pm 0.066^{\mathrm{r}}$ \\
\hline & RB4 & ND & ND & $20.67 \pm 0.124^{\mathrm{r}}$ & $1.73 \pm 0.111^{\mathrm{q}}$ & $1.06 \pm 0.008^{\mathrm{q}}$ & ND & $23.46 \pm 0.112^{\mathrm{r}}$ \\
\hline & RB5 & ND & ND & $19.51 \pm 0.090^{\mathrm{s}}$ & $2.09 \pm 0.046^{\mathrm{p}}$ & $1.66 \pm 0.056^{\mathrm{p}}$ & ND & $23.26 \pm 0.131^{\mathrm{r}}$ \\
\hline \multirow[t]{5}{*}{ Mustard oil } & MT1 & ND & ND & $3.74 \pm 0.065^{\mathrm{w}}$ & $2.56 \pm 0.029^{x}$ & $0.667 \pm 0.013^{z}$ & ND & $6.97 \pm 0.096^{\mathrm{v}}$ \\
\hline & MT2 & ND & ND & $3.12 \pm 0.014^{\mathrm{x}}$ & $1.18 \pm 0.027^{\mathrm{z}}$ & $0.859 \pm 0.018^{y}$ & ND & $5.16 \pm 0.038^{\mathrm{y}}$ \\
\hline & MT3 & ND & ND & $3.11 \pm 0.011^{\mathrm{x}}$ & $1.25 \pm 0.024^{\mathrm{z}}$ & $1.24 \pm 0.025^{\mathrm{w}}$ & ND & $5.61 \pm 0.009^{\mathrm{x}}$ \\
\hline & MT4 & ND & ND & $2.48 \pm 0.047^{\mathrm{y}}$ & $3.20 \pm 0.033^{\mathrm{w}}$ & $0.701 \pm 0.024^{z}$ & ND & $6.38 \pm 0.079^{w}$ \\
\hline & MT5 & ND & ND & $2.02 \pm 0.049^{\mathrm{z}}$ & $1.45 \pm 0.024^{\mathrm{y}}$ & $1.09 \pm 0.044^{\mathrm{x}}$ & ND & $4.56 \pm 0.031^{z}$ \\
\hline \multirow[t]{5}{*}{ Palm Olein } & PO1 & $0.249 \pm 0.0008^{n}$ & $0.929 \pm 0.0007^{1}$ & $38.95 \pm 0.0009^{n}$ & $4.67 \pm 0.0009^{k}$ & $0.275 \pm 0.014^{\mathrm{k}}$ & ND & $45.07 \pm 0.013^{n}$ \\
\hline & $\mathrm{PO} 2$ & $0.374 \pm 0.0007^{\mathrm{m}}$ & $0.825 \pm 0.001^{\mathrm{n}}$ & $41.09 \pm 0.019^{\mathrm{k}}$ & $2.92 \pm 0.023^{\mathrm{m}}$ & $0.277 \pm 0.0006^{\mathrm{k}}$ & ND & $45.49 \pm 0.033^{1}$ \\
\hline & $\mathrm{PO} 3$ & $0.235 \pm 0.001^{\circ}$ & $0.818 \pm 0.001^{\circ}$ & $36.49 \pm 0.007^{\circ}$ & $2.04 \pm 0.0004^{\circ}$ & $0.265 \pm 0.0005^{\mathrm{k}}$ & ND & $39.85 \pm 0.005^{\circ}$ \\
\hline & PO4 & $2.56 \pm 0.0004^{\mathrm{k}}$ & $1.87 \pm 0.0002^{\mathrm{k}}$ & $39.96 \pm 0.0006^{1}$ & $2.31 \pm 0.0005^{\mathrm{n}}$ & $0.283 \pm 0.0003^{\mathrm{k}}$ & ND & $46.97 \pm 0.002^{\mathrm{k}}$ \\
\hline & PO5 & $1.22 \pm 0.0005^{1}$ & $0.858 \pm 0.0005^{\mathrm{m}}$ & $39.31 \pm 0.013^{\mathrm{m}}$ & $3.65 \pm 0.001^{1}$ & $0.265 \pm 0.0003^{\mathrm{k}}$ & ND & $45.30 \pm 0.014^{\mathrm{m}}$ \\
\hline
\end{tabular}

Values with the same superscript in the column are not significantly different $(\mathrm{p}>0.05)$

*Detection limit: $0.0001 \%$

\section{Unsaturated fatty acids}

Monounsaturated fatty acids (MUFA) are chemically classified as fatty acids containing a single double bond where polyunsaturated fatty acids (PUFA) containing two or more double bonds in contrast (Schwingshackl and Hoffmann, 2012). The distribution of monounsaturated fatty from 0.069 (in SF3) to $0.11 \%$ (in SF2).In case of palm olein, the amount of palmitoleic acid ranged from 0.097 to $0.318 \%$ and all the samples varied significantly. Highest amount was found in PO1 $(0.318 \%)$ while lowest in $\mathrm{PO} 3$ $(0.0 .097 \%)$.Oleic acid (C18:1), the main MUFA provided in the diet ( $\sim 90 \%$ of all MUFAs) (Schwingshackl and Hoffmann, 2012), level was found almost similar in all the 
samples of the soybean oil. In case of sunflower oil, oleic acid content varied significantly and ranged from 24.25 to $31.35 \%$. Highest content of oleic acid was found in sample SF4 and lowest in sample SF1. In rice bran oil, the oleic acid content ranged from 41.89 to $43.22 \%$. Highest content was found in sample RB1 and lowest in sample RB3. In mustard oil, the oleic acid content ranged from 12.26 to $16.19 \%$. Highest content was found in MT2 while lowest in MT4. In palm olein, highest level of oleic acid was found in sample PO3 (45.82\%) while lowest in PO4 (40.89\%). Erucic acid (C22:1) was found only in mustard oil ranging from 46.46 to $52.67 \%$ where MT2 and MT3 are significantly indifferent. According to Codex standard (CODEX-STAN 210 - 1999), erucic acid content is mainly present in mustard oil (22-50\%) and the present study confirms this result. Eicosenoic acid (C20:1) is another predominant mono unsaturated fatty acid, was found highest concentration in mustard oil (8.16 to $9.16 \%)$ and lowest in palm olein $(0.102$ to $0.165 \%)$. In case of soybean oil, sunflower oil and rice bran oil, eicosenoic acid level was found 0.147 to $0.417 \%, 0.117$ to $0.518 \%$ and 0.201 to $0.734 \%$ respectively.

In this study, it can be observed that mustard oil is the richest source of total MUFA ranging from 69.30 to $75.87 \%$ where soybean and sunflower oils have almost similar quantity of MUFA like rice bran and palm oleins. In the previous study, MUFA was found $21-28.5 \%$ in soybean oils, $15-45 \%$ in sunflower oils, almost $41 \%$ in rice bran oils, $41-57 \%$ in mustard oils and 39-41\% in palm oleins (Chowdhury et al., 2007; Kostik et al., 2013; Zambiazi et al., 2007). The results of this study may differ with previous studies due to different varieties, locations and seasons. The benefits of MUFA may be described by the increase of HDL-cholesterol when it replaces carbohydrates and also the substitution of SFA with MUFA exerts favorable effects on LDL-cholesterol and the ratio of total cholesterol to HDL-cholesterol (Schwingshackl and Hoffmann, 2012).

Linoleic acid, one of the most common omega- 6 fatty acids, was found highest in sunflower oils (58.33 to $64.65 \%)$ and lowest in palm olein oils (10.87to $13.78 \%$ ). In the study, soybean oils contain a considerable amount of linoleic acid, 54.45 to $56.39 \%$.Several studies concluded that higher linoleic acid intakes may improve insulin resistance (Summers et al., 2002) and decrease the incidence of diabetes mellitus (Salmeron et al., 2001) and higher serum linoleic acid levels are related with lower blood pressure (Superko et al., 2014). Linolenic acid (omega-3 fatty acid) was found mostly in soybean (6.53 to $7.59 \%$ ) and mustard oils (6.92 to $9.68 \%$ ). In case of sun flower oil, rice bran oil and palm olein, linolenic acid ranged from 0.115 to $0.152 \%, 0.347$ to $0.742 \%$ and 0.152 to $0.338 \%$ respectively. Linolenic acid is very important for human because mammalian cells cannot convert omega- 6 to omega- 3 fatty acids for the lacking of converting enzyme, omega-3 desaturase (Simopoulos, 2002).

Table III shows that total PUFA is high in soybean and sunflower oils ranging from 61.33 to $62.34 \%$ and 58.48 to $64.78 \%$ respectively. The lowest PUFA was in palm olein varying from 11.02 to $14.12 \%$. Nearly similar results were found in previous studies where PUFA in soybean oil was $56-63 \%$, sunflower oil was $46-71 \%$, rice bran oil was almost $37 \%$, mustard oil was $30-42 \%$ and palm olein was 10-12\% (Chowdhury et al., 2007, Kostik et al., 2013, Zambiazi et al., 2007). In case of rice bran and mustard oil, PUFA was found 31 to $34.97 \%$ and 19.57 to $25.09 \%$ respectively. As most PUFA was found in sunflower oils in this experiment, sunflower oil is prone to quick rancidity. Peroxide value of sunflower oil increases most rapidly with time followed by soybean oil for presence of more polyunsaturated fatty acids (Khan et al., 2015). Although PUFA may be more efficient than MUFA in lowering total blood serum cholesterol without affecting HDL cholesterol, oils with high levels of PUFA have a tendency to form trans fatty acid as well as peroxides which are detrimental to health (Beardsell et al., 2002).

\section{Vitamin A}

Vitamin A contents of five types of commercial vegetable oils (Soybean oil, sunflower oil, rice bran oil, mustard oil and palm olein) were shown in Table IV. In soybean oils, vitamin A content was 1.88, 1.67, 1.83, 2.85 and 2.06 ppm in SB1, SB2, SB3, SB4 and SB5 respectively. It can be clearly seen that highest vitamin A content was found in SB4 while lowest found in SB3. SB1 and SB3 had almost the same amount of vitamin A. SB2 and SB4 were significantly different from the others in terms of vitamin A while SB5 was significantly indifferent from SB1 and SB3. According to BSTI standards, vitamin A fortification level all edible oils of should be 15-30 ppm. However, the amount of vitamin A content did not comply with BSTI standard for fortified soybean oil (BDS 1769: 2014). Furthermore, among the rice bran oils, vitamin A content was $7.23,6.88,1.34,1.53$ and 2.77 ppm in RB1, $\mathrm{RB} 2, \mathrm{RB} 3, \mathrm{RB} 4$ and $\mathrm{RB} 5$ respectively that were significantly different from each other. The highest vitamin A content (7.23ppm) was found in RB1 while the lowest $(1.34 \mathrm{ppm})$ in RB3. Although vitamin A content of RB1 and RB2 was much higher than that of soybean oil and other rice bran oil samples, yet it was not within the range declared in BSTI standard for fortified rice bran oil (BDS 1886: 2014). In addition, in palm oleins vitamin A content was 1.72, 10.57 and $1.46 \mathrm{ppm}$ in PO1, PO3 and PO4 respectively, but was not detected in two other palm olein samples (PO2 and PO5). 
Table III. Monounsaturated fatty acids (MUFA)* and Polyunsaturated fatty acids (PUFA) (Mean \pm SEM) in the vegetable oils

\begin{tabular}{|c|c|c|c|c|c|c|c|c|c|}
\hline $\begin{array}{l}\text { Sample } \\
\text { Name }\end{array}$ & $\begin{array}{l}\text { Sample } \\
\text { Code }\end{array}$ & $\begin{array}{c}\text { Palmitoleic } \\
(\%)\end{array}$ & $\begin{array}{l}\text { Oleic } \\
(\%)\end{array}$ & $\begin{array}{c}\text { Linoleic } \\
(\text { Omega -6) } \\
(\%)\end{array}$ & $\begin{array}{c}\text { Linolenic } \\
\text { (Omega -3) } \\
(\%)\end{array}$ & $\begin{array}{c}\text { Eicosenoic } \\
(\%)\end{array}$ & $\begin{array}{c}\text { Erucic } \\
(\%)\end{array}$ & $\begin{array}{c}\text { Total MUFA } \\
(\%)\end{array}$ & $\begin{array}{c}\text { Total PUFA } \\
(\%)\end{array}$ \\
\hline Soybean & SB1 & ND & $21.93 \pm 0.319^{a b}$ & $54.77 \pm 0.448^{\mathrm{bc}}$ & $7.57 \pm 0.049^{\mathrm{a}}$ & $0.281 \pm 0.008^{\mathrm{b}}$ & ND & $22.21 \pm 0.311^{\text {ab }}$ & $62.34 \pm 0.449^{\text {ab }}$ \\
\hline \multirow[t]{4}{*}{ Oil } & SB2 & ND & $22.89 \pm 0.549^{\mathrm{a}}$ & $55.41 \pm 0.225^{\mathrm{b}}$ & $6.53 \pm 0.145^{\mathrm{b}}$ & $0.417 \pm 0.006^{\mathrm{a}}$ & ND & $23.30 \pm 0.551^{\mathrm{a}}$ & $61.94 \pm 0.239^{\mathrm{bc}}$ \\
\hline & SB3 & ND & $21.98 \pm 0.051^{\mathrm{ab}}$ & $56.39 \pm 0.094^{\mathrm{a}}$ & $6.86 \pm 0.204^{b}$ & ND & ND & $21.98 \pm 0.051^{\mathrm{b}}$ & $63.25 \pm 0.245^{\mathrm{a}}$ \\
\hline & SB4 & ND & $22.63 \pm 0.321^{\mathrm{ab}}$ & $54.74 \pm 0.161^{\mathrm{bc}}$ & $6.59 \pm 0.154^{b}$ & $0.274 \pm 0.027^{\mathrm{b}}$ & ND & $22.91 \pm 0.334^{\mathrm{ab}}$ & $61.33 \pm 0.140^{\mathrm{c}}$ \\
\hline & SB5 & $\mathrm{ND}$ & $21.56 \pm 0.385^{\mathrm{b}}$ & $54.45 \pm 0.110^{\mathrm{c}}$ & $7.59 \pm 0.179^{\mathrm{a}}$ & $0.147 \pm 0.025^{\mathrm{c}}$ & ND & $21.71 \pm 0.389^{\mathrm{b}}$ & $62.04 \pm 0.289^{\mathrm{bc}}$ \\
\hline Sunflower & SF1 & $\mathrm{ND}^{\mathrm{h}}$ & $24.25 \pm 0.039^{i}$ & $64.65 \pm 0.036^{\mathrm{e}}$ & $0.138 \pm 0.007^{\mathrm{e}}$ & $0.518 \pm 0.009^{e}$ & ND & $24.77 \pm 0.048^{i}$ & $64.78 \pm 0.035^{\mathrm{e}}$ \\
\hline \multirow[t]{4}{*}{ Oil } & $\mathrm{SF} 2$ & $0.110 \pm 0.012^{\mathrm{e}}$ & $27.58 \pm 0.024^{\mathrm{h}}$ & $61.84 \pm 0.053^{\mathrm{f}}$ & ND & $0.117 \pm 0.012^{\mathrm{g}}$ & ND & $27.81 \pm 0.004^{\mathrm{h}}$ & $61.84 \pm 0.053^{\mathrm{f}}$ \\
\hline & $\mathrm{SF} 3$ & $0.069 \pm 0.0007^{\mathrm{g}}$ & $30.11 \pm 0.009^{\mathrm{f}}$ & $61.19 \pm 0.027^{\mathrm{g}}$ & $0.115 \pm 0.006^{\mathrm{f}}$ & $0.128 \pm 0.009^{\mathrm{g}}$ & ND & $30.31 \pm 0.017^{\mathrm{f}}$ & $61.31 \pm 0.023^{\mathrm{g}}$ \\
\hline & SF4 & $0.080 \pm 0.001^{\mathrm{f}}$ & $31.35 \pm 0.018^{\mathrm{e}}$ & $58.33 \pm 0.015^{\mathrm{i}}$ & $0.152 \pm 0.0001^{\mathrm{e}}$ & $0.366 \pm 0.0005^{\mathrm{f}}$ & ND & $31.80 \pm 0.017^{\mathrm{e}}$ & $58.48 \pm 0.014^{\mathrm{i}}$ \\
\hline & SF5 & $0.086 \pm 0.001^{\mathrm{f}}$ & $28.95 \pm 0.048^{\mathrm{g}}$ & $60.92 \pm 0.044^{\mathrm{h}}$ & ND & $0.118 \pm 0.0004^{\mathrm{g}}$ & $\mathrm{ND}$ & $29.15 \pm 0.047^{\mathrm{g}}$ & $60.92 \pm 0.044^{\mathrm{h}}$ \\
\hline Rice Bran & RB1 & ND & $43.22 \pm 0.175^{9}$ & $31.23 \pm 0.040^{\mathrm{h}}$ & $0.578 \pm 0.035^{f}$ & $0.201 \pm 0.0008^{\mathrm{h}}$ & ND & $43.42 \pm 0.175^{\mathrm{r}}$ & $31.81 \pm 0.048^{\mathrm{r}}$ \\
\hline \multirow[t]{4}{*}{ Oil } & RB2 & ND & $42.65 \pm 0.151^{\mathrm{r}}$ & $32.13 \pm 0.085^{\mathrm{g}}$ & $0.650 \pm 0.0005^{\mathrm{fg}}$ & $0.418 \pm 0.004^{\mathrm{g}}$ & $\mathrm{ND}$ & $43.07 \pm 0.148^{\mathrm{r}}$ & $32.78 \pm 0.085^{\mathrm{q}}$ \\
\hline & RB3 & $\mathrm{ND}$ & $41.89 \pm 0.071^{\mathrm{s}}$ & $34.62 \pm 0.076^{\mathrm{e}}$ & $0.347 \pm 0.012^{\mathrm{g}}$ & ND & ND & $41.89 \pm 0.071^{\mathrm{s}}$ & $34.97 \pm 0.078^{\mathrm{p}}$ \\
\hline & RB4 & ND & $44.89 \pm 0.082^{\mathrm{p}}$ & $30.26 \pm 0.025^{\mathrm{i}}$ & $0.742 \pm 0.016^{\mathrm{e}}$ & $0.649 \pm 0.020^{\mathrm{f}}$ & ND & $45.54 \pm 0.101^{\mathrm{p}}$ & $31.00 \pm 0.013^{\mathrm{s}}$ \\
\hline & RB5 & ND & $43.10 \pm 0.048^{q}$ & $32.40 \pm 0.068^{\mathrm{f}}$ & $0.504 \pm 0.093^{\mathrm{f}}$ & $0.734 \pm 0.016^{\mathrm{e}}$ & ND & $43.84 \pm 0.054^{9}$ & $32.91 \pm 0.086^{9}$ \\
\hline Mustard & MT1 & ND & $13.73 \pm 0.041^{y}$ & $14.69 \pm 0.028^{x}$ & $8.00 \pm 0.005^{y}$ & $8.05 \pm 0.026^{z}$ & $48.55 \pm 0.078^{y}$ & $70.33 \pm 0.12^{y}$ & $22.70 \pm 0.026^{x}$ \\
\hline \multirow[t]{4}{*}{ oil } & MT2 & ND & $16.19 \pm 0.011^{\mathrm{w}}$ & $15.12 \pm 0.014^{\mathrm{w}}$ & $8.49 \pm 0.095^{\mathrm{x}}$ & $8.67 \pm 0.021^{y}$ & $46.36 \pm 0.064^{z}$ & $71.23 \pm 0.09^{\mathrm{x}}$ & $23.61 \pm 0.084^{\mathrm{w}}$ \\
\hline & MT3 & ND & $13.68 \pm 0.028^{y}$ & $15.42 \pm 0.010^{v}$ & $9.68 \pm 0.171^{\mathrm{w}}$ & $9.16 \pm 0.013^{x}$ & $46.46 \pm 0.177^{\mathrm{z}}$ & $69.30 \pm 0.189^{\mathrm{z}}$ & $25.09 \pm 0.181^{\mathrm{v}}$ \\
\hline & MT4 & ND & $12.26 \pm 0.021^{z}$ & $13.67 \pm 0.029^{y}$ & $6.92 \pm 0.060^{z}$ & $8.58 \pm 0.028^{y}$ & $52.18 \pm 0.115^{\mathrm{x}}$ & $73.02 \pm 0.141^{\mathrm{w}}$ & $20.60 \pm 0.069^{\mathrm{y}}$ \\
\hline & MT5 & $\mathrm{ND}$ & $15.03 \pm 0.019^{\mathrm{x}}$ & $12.55 \pm 0.060^{\mathrm{z}}$ & $7.02 \pm 0.022^{\mathrm{z}}$ & $8.16 \pm 0.076^{z}$ & $52.67 \pm 0.065^{\mathrm{w}}$ & $75.87 \pm 0.069^{\mathrm{v}}$ & $19.57 \pm 0.050^{z}$ \\
\hline Palm & PO1 & $0.318 \pm 0.0005^{\mathrm{k}}$ & $42.16 \pm 0.029^{\mathrm{n}}$ & $12.12 \pm 0.014^{1}$ & $0.171 \pm 0.003^{\mathrm{m}}$ & $0.165 \pm 0.0006^{k}$ & $\mathrm{ND}$ & $42.64 \pm 0.030^{\mathrm{n}}$ & $12.29 \pm 0.018^{1}$ \\
\hline \multirow[t]{4}{*}{ Olein } & $\mathrm{PO} 2$ & $0.249 \pm 0.0004^{\mathrm{m}}$ & $42.53 \pm 0.035^{\mathrm{m}}$ & $11.45 \pm 0.011^{\mathrm{n}}$ & $0.160 \pm 0.0003^{\mathrm{n}}$ & $0.129 \pm 0.0005^{\mathrm{m}}$ & ND & $42.91 \pm 0.035^{\mathrm{m}}$ & $11.61 \pm 0.011^{\mathrm{n}}$ \\
\hline & $\mathrm{PO} 3$ & $0.097 \pm 0.0002^{\circ}$ & $45.82 \pm 0.004^{\mathrm{k}}$ & $13.78 \pm 0.002^{\mathrm{k}}$ & $0.338 \pm 0.0005^{1}$ & $0.113 \pm 0.0003^{\mathrm{n}}$ & ND & $46.03 \pm 0.004^{\mathrm{k}}$ & $14.12 \pm 0.002^{\mathrm{k}}$ \\
\hline & PO4 & $0.112 \pm 0.0002^{\mathrm{n}}$ & $40.89 \pm 0.003^{\circ}$ & $11.55 \pm 0.001^{\mathrm{m}}$ & $0.335 \pm 0.0006^{1}$ & $0.132 \pm 0.0004^{1}$ & ND & $41.14 \pm 0.003^{\circ}$ & $11.88 \pm 0.001^{\mathrm{m}}$ \\
\hline & PO5 & $0.296 \pm 0.0003^{1}$ & $43.28 \pm 0.013^{1}$ & $10.87 \pm 0.0007^{\circ}$ & $0.152 \pm 0.0003^{\circ}$ & $0.102 \pm 0.0002^{\circ}$ & ND & $43.68 \pm 0.013^{1}$ & $11.02 \pm 0.001^{\circ}$ \\
\hline
\end{tabular}

Values with the same superscript in the column are not significantly different $(\mathrm{p}>0.05)$

*Detection limit: $0.0001 \%$

Table IV. Vitamin A (Mean \pm SEM) content of the vegetable oils

\begin{tabular}{cccccccccc}
\hline \multicolumn{2}{c}{ Soybean Oil } & \multicolumn{2}{c}{ Sunflower Oil } & \multicolumn{2}{c}{ Rice Bran Oil } & \multicolumn{2}{c}{ Mustard oil } & \multicolumn{2}{c}{ Palm Olein } \\
\hline $\begin{array}{c}\text { Sample } \\
\text { Code }\end{array}$ & $\begin{array}{c}\text { Vitamin A } \\
(\mathrm{ppm})^{*}\end{array}$ & $\begin{array}{c}\text { Sample } \\
\text { Code }\end{array}$ & $\begin{array}{c}\text { Vitamin A } \\
(\mathrm{ppm})^{*}\end{array}$ & $\begin{array}{c}\text { Sample } \\
\text { Code }\end{array}$ & $\begin{array}{c}\text { Vitamin A } \\
(\mathrm{ppm})^{*}\end{array}$ & $\begin{array}{c}\text { Sample } \\
\text { Code }\end{array}$ & $\begin{array}{c}\text { Vitamin A } \\
(\mathrm{ppm})^{*}\end{array}$ & $\begin{array}{c}\text { Sample } \\
\text { Code }\end{array}$ & $\begin{array}{c}\text { Vitamin A } \\
(\mathrm{ppm})^{*}\end{array}$ \\
\hline SB1 & $1.88 \pm 0.006^{\text {bc }}$ & SF1 & ND & RB1 & $7.23 \pm 0.016^{\mathrm{w}}$ & MT1 & ND & PO1 & $1.72 \pm 0.003^{\mathrm{e}}$ \\
SB2 & $1.67 \pm 0.009^{\mathrm{d}}$ & SF2 & ND & RB2 & $6.88 \pm 0.008^{\mathrm{x}}$ & MT2 & ND & PO2 & ND \\
SB3 & $1.83 \pm 0.006^{\text {bc }}$ & SF3 & ND & RB3 & $1.34 \pm 0.005^{\mathrm{z}}$ & MT3 & ND & PO3 & $10.57 \pm 0.02^{\mathrm{d}}$ \\
SB4 & $2.85 \pm 0.017^{\mathrm{a}}$ & SF4 & ND & RB4 & $1.53 \pm 0.009^{\mathrm{z}}$ & MT4 & ND & PO4 & $1.46 \pm 0.011^{\mathrm{e}}$ \\
SB5 & $2.06 \pm 0.004^{\mathrm{b}}$ & SF5 & ND & RB5 & $2.77 \pm 0.011^{\mathrm{y}}$ & MT5 & ND & PO5 & ND
\end{tabular}

Values with the same superscript in the column are not significantly different $(p>0.05)$.

*Detection limit: 0.1 ppm 
PO1 and PO4 were significantly indifferent in terms of vitamin A whereas PO3 had a high amount of vitamin A even the value did not comply with BDS 1770: 2014, BSTI standard for fortified palm oil. Thus results of vitamin A content in the soybean oils, rice bran oils and palm oleins studied were not optimal due to some technical reasons. Industries should estimate an adequate overage to fortify vitamin A during production to account for predictable losses during handling, shipping and storage. Furthermore, proper quality assurance system with regular review and monitoring is required. It is also essential to evaluate the biological effectiveness periodically for confirming the expected output of the fortification program (Dary and Mora, 2002). More importantly, vitamin A in vegetable oils does not have good storage stability if they are not well protected from light and oxygen (Laillou et al., 2012).

Although BSTI set standard for fortified edible sunflower oil (BDS 1773: 2016), as the studied sunflower oils were imported from developed countries where vitamin A deficiency is not an important issue, Vitamin A was not found in any of the sunflower oils. Vitamin A could not be found in any mustard oil analyzed as well since mustard oil was not under consideration of vitamin A fortification program due to some technological difficulties.

\section{Conclusion}

FFA, PV and IV were within the BSTI standard in all edible oils studied, hence, quality of the oils were acceptable. The fatty acid composition illustrated that soybean and sunflower oil are very healthy in terms of total PUFA content although they should be consumed carefully considering the shelf life as PUFA oxidizes very rapidly. Although all soybean oils, rice bran oils and only $60 \%$ of the palm oleins studied contains vitamin A, the level was far below the standard value (15-30 ppm). Further study is needed to follow the implementation of vitamin A fortification program. According to the 'National Edible Oil Fortification Law, 2013', Vitamin A should be fortified to the desired value in all edible oils of Bangladesh to reduce the vitamin A deficiency of the mass population of Bangladesh.

\section{Acknowledgement}

This article is an outcome of a R\&D project of the Institute of Food Science and Technology (IFST), Bangladesh Council of Scientific and Industrial Research (BCSIR), Dhaka, Bangladesh. Authors are thankful to BCSIR for providing necessary funds and instruments to carry out the research. The instruments used in this work have been supported by an ADP project funded by the Ministry of Science \& Technology, Government of Bangladesh. the assistance of all laboratory staffs and technical personnel of Oilseed and Lipid Technology section, IFST, BCSIR, is also acknowledged.

\section{References}

AOAC (2005), Official Method of Analysis of the Association of Official, Analytical Chemist, Gaithersburg, USA 41: 6-7,11-13.

BSTI, Bangladesh standards Specification for vegetable oilsa. BDS 1769: 2014 (Fortified soybean oil), b. BDS 1773: 2016 (Fortified sunflower oil), c. BDS 1770: 2014 (Fortified edible palm oil), d. BDS 1886: 2014 (Fortified edible rice bran oil), e. BDS 25: 2014 (Edible mustard oil)

Beardsell D, Francis J and Ridley D (2002), Health promoting constituents in plant derived edible oils, $J$ of Food Lipids 9: 1-34. DOI: org/10.1111/j.17454522.2002.tb00205.x

Crapiste GH, Brevedan MIV, Carelli AA (1999). Oxidation of Sunflower Oil during Storage, J Am Oil Chem Soc. 76(12): 1437-1443. doi.org/10.1007/s11746-999$0181-5$

Chowdhury K, Banu LA, Khan S and Latif A (2007), Studies on the Fatty Acid Composition of Edible Oil, Bangladesh J. Sci. Ind. Res. 42(3): 311-316. DOI: org/10.3329/bjsir.v42i3.669

Chowdhury K, Obaid M, Lisa SA and Karim R (2014), Evaluation on edible oil quality parameters as well as nutritional value of flaxseed (linseed) oil in Bangladesh, J Chem Bio Phy Sci. 5(1): 401-412.

CODEX-STAN, Codex Standards for Fats and Oils from Vegetable Sources. Codex Standard for Named Vegetable Oils (CODEX-STAN 210-1999).

Dary O and Mora JO (2002), Food fortification to reduce vitamin A deficiency: International vitamin A consultative group recommendations, J Nutr. 132: 2927S-2933S.

Egbuna SO (2015), Optimization of the effects of degumming parameters on the removal of phosphatides and the stability of refined palm oil, Int $J$ Sci Res Eng Tech. 4(9): 958-972. DOI.org/10.1016/j.seppur.2017.07.049

Fursule RA, Kulkarni JS and Agakar PH (2006), Biochemistry - Basic and Applied, $3^{\text {rd }}$ Ed., NiraliPrakashan, Pune, pp 6-8. 
Khan S, Lisa SA, Obaid M and Chowdhury K (2015), Tocopherol content of vegetable oils/fats and their oxidative deterioration during storage, World J Pharm Sci. 4(4): 1537-1548. DOI:org/10.1007/ s11746-009-1526-9

Kostik V, Memeti S and Bauer B (2013), Fatty acid composition of edible oils and fats, J Hygien Eng Des. 4: 112-116.

Laillou A, Hafez SA, Mohmoud AH, Mansour M, Rohaner F, Fortin S, Berger J, Ibrahim NA and Moench-Pfanner $\mathrm{R}$ (2012), Vegetable oil of poor quality is limiting the success of fortification with vitamin A in Egypt, Food and Nutrition Bulletin 33(3): 186-193.

Llorent-Martinez EJ, Ortega-Barrales P, Fernadez-de-Cordova ML, Dominguez-Vidal A and Ruiz-Medina A (2011), Investigation by ICP-MS of trace element levels in vegetable edible oils produced in Spain, Food Chemistry 127: 1257-1262.

Miller GD, Jarvis JK and McBean LD (2000), Handbook of Dairy Foods and Nutrition, $2^{\text {nd }}$ Ed, CRC Press, Boca Raton, London New York Washington D.C, pp 71.

Ratledge C (2004), Fatty acid biosynthesis in microorganisms being used for single cell oil production, Biochimie $\quad \mathbf{8 6}(11)$ : 807-815. DOI:org/10.1016/j.biochi.2004.09.017

Schwingshackl L and Hoffmann G (2012), Monounsaturated Fatty Acids and Risk of Cardiovascular Disease: Synopsis of the Evidence Available from Systematic Reviews and Meta-Analyses, Nutrients. 4(12): 1989-2007.
Salmeron J, Hu FB, Manson JE, Stampfer MJ, Colditz GA, Rimm EB,Willett WC (2001), Dietary fat intake and risk of type 2 diabetes in women, Am J Clin Nutr. 73: $1019-1026$.

Simopoulos AP (2002), The importance of the ratio of omega-6/ omega-3 essential fatty acids, Biomed Pharmacother. 56: 365-379. DOI:org/10.1016/ S0753-3322(02)00253-6

Summers LK, Fielding BA, Bradshaw HA, Ilic V, Beysen C, Clark ML, Moore NR, Frayn KN (2002), Substituting dietary saturated fat with polyunsaturated fat changes abdominal fat distribution and improves insulin sensitivity, Diabetologia 45: $369-377$.

Superko HR, Superko AR, Lundberg GP, Margolis B, Garrett BC, Nasir K, and Agatston AS (2014), Omega-3 fatty acid blood levels clinical significance update, CurrCardiovasc Risk Rep. 8(11): 407.

UNICEF Factsheet (2014), Fortification of edible oil in Bangladesh.

WHO (World Health Organization) (2018), Micronutrient deficiencies. (http:// www.who. int/nutrition/ topics/vad/en/)

Zambiazi RC, Przybylski R, Zambiazi MW and Mendonca CB (2007), Fatty acid composition of vegetable oils and fats, B.CEPPA, Curitiba. 25: 111-120. DOI: http://dx.doi.org/10.5380/cep.v25i1.8399 